\title{
Reconstruction of Character Education Model in Higher Education through Project Netizen I Love Products Indonesian
}

\author{
Nurul Zuriah, Mohammad Syaifuddin and Marhan Taufik \\ Faculty of Teacher Training and Education \\ University of Muhammadiyah Malang \\ Malang, Indonesia \\ zuriahnurul@gmail.com
}

\begin{abstract}
National character education has a strategic role in national development. To fulfill this required a grand design and development of character education model as part of efforts to build the character of the nation. This article contains the results of higher education research "Reconstruction of a National Education Character a Model Three Pillars Education center to strengthen the sense of love and pride of Indonesian products (I Love Indonesian Products - ACPI)", by integrating character education at Civics education through Research and Development. The objective of the research is to develop and develop character education model that can strengthen the love and pride of Indonesian products based on Tri pillar of Education center in Higher Education. Method of reconstruction of education the character is implemented in three stages, namely: a. Concept, b. Product, and c. Trial through action research and quasi experiments. Through this reconstruction, the results are presented as follows: (1) Character Education Model based on Education center through ACPI Project Netizen, designed based on ADDIE theory; (2) learning outcome of product in the form of basic character value developed from moral knowing, moral felling and moral action (3) Product and Publication of reconstruction result of Character Education model developed.
\end{abstract}

Keywords- character education; civic education; I Love Indonesian products; reconstruction; netizen project

\section{INTRODUCTION}

The character education of the nation has a strategic role in national development. To fulfill this required a grand design of character education as part of efforts to build the character of the nation. Character education regulation is regulated in (1) of the 1945 Amendment, (2) of Law no. (4) Government Regulation No. 17 of 2010 on Management of Education Implementation, (5) Presidential Instruction No.1 of 2010 and other Regulation of the Minister of National Education as the basis of its operation [1]. For a nation the characters are the virtues of virtue attached to each individual citizen and then manifest as the nation's collective personality and identity.

Character serves as a mental and ethical force that encourages a nation to realize its national ideal and display comparative, competitive, and dynamic advantages among the
Gentiles. In the Grand Design, the development of the National Character Education of the Ministry of Education states that 3 aspects of the noble character formers are [2] : (a) Religion, Pancasila, 1945 Constitution and National Education Law, (b) Educational, Psychological, Value and Socio- c) The best experience and real practice [1]. Dignity of a nation is closely related to the education experienced by a nation itself. Because with the education of a nation can determine the character, attitude and behavior when dealing with other nations in the world. Education is very important in the development of a nation, because with the education of a nation is not easily colonized by other nations, and with education a nation can achieve advancements and developments that can bring it to realize the ideals of the nation, and with education also a the nation can catch up from other nations in the world. The various achievements and achievements that have been achieved by the Indonesian nation, whether in the field of politics, economy, security and people's welfare after independence, still cannot realize the ideals of the nation of Indonesia as a strong, big, respected and respected nation in the midst of the nation in the world [3]. This provides a challenge for the Indonesian nation to make changes. Changes that can make this nation a developed nation. The advanced nation is determined by a formidable, individual and collective mentality of Indonesian citizens. To realize the ideals of the Indonesian people still need the views that require a fundamental change of the pattern of education in Indonesia so far. The view that is currently the concern of many parties is the mental revolution presented by President Joko Widodo. Character education becomes very important because of three things [4]; 1) macro, there has been a decline in the character of the nation characterized by high index of corruption, thuggery and violence; (2) micro-education in the world also a lot of cases of bullying, brawl between students, weakness of the curriculum system and learning process that is not conducive to the formation of national character; (3) Jokowi - JK as elected president and vice-president since the campaign has affirmed the need for a mental revolution relating to three main things of political sovereignty, economic independence and personality in culture. 
Character building is very important. Higher Education becomes the main agent in building human Indonesian who have character, virtuous character, and noble. The Indonesian people want to have a superior and noble civilization. Civilization can be achieved if the people of Indonesia into a good society. Ideal societies like this can be realized if the nation of Indonesia has good morals, human moral and ethical good, and humans who speak and behave well as well. For that we need to find the best way to build and develop human character and nation of Indonesia in order to have good character, superior and noble. The right for that is through education, because education has an important and central role in the development of human potential, including mental potential. Through education is expected to happen a transformation that can sprout up positive character, and change bad habits of life to be good. Character serves as a mental and ethical force that encourages a nation to realize its national ideal and display comparative, competitive, and dynamic advantages among other nations. Based on the existing phenomenon and the results of previous research there are two things that should receive serious attention. First, the emergence of the phenomenon of decline noble character among students. Secondly, there is no model of character education in universities in accordance with religious and cultural values that can shape the character of students who love Indonesian products and support food self-sufficiency. Therefore it is necessary to find and formulate the character education model of the nation to love Indonesian products and support effective food self-sufficiency, and can be implemented in the college environment.

\section{THEORETICAL}

Based on the description in advance, it is time for the campus to promote character education concretely for students. Achievement of intellectuality and academic values must be accompanied by the inculcation of character values and good "akhlakul kharimah" (good character). Student's social and managerial abilities must be based on faith and devotion to God Almighty, have initiative and creativity have the traits honest, sincere, devoted, and humble devotion are born from each individual to establish interaction among the individual for the realization of the integrity of the nation.

It is intended that students are not only intellectually and socially smart, but also have good moral integrity, and have a high empathy and solidarity to the surrounding environment. Character education is not Indoctrination, students should be encouraged to find the reasons underlying moral decisions, through the enhancement of Logical, Grammatical and Rhetoric abilities [5]. Embedded / hidden curriculum needs to be done to learn not only to transfer knowledge but more to learning to think, reading skill, writing skill, articulate communication skill, nationalism and state defense. These activities can be done through curricular, extra and cocurricular activities. The goal is to develop the ability to control the actions necessary for a person to truly understand the moral judgments he or she is taking, identifying good reasons to accept and unfavorable reasons to be rejected or changed. In the end the student must be able to formulate the changes that need to be done.
Learning should create social settings that enable the implementation of the knowledge gained to solve existing problems in society. Furthermore, character education / moral / values should be focused on the link between moral thinking (moral thinking) and moral action (moral action). The concept of morality needs to be integrated with experience in social life. Moral thinking can be developed, among other things, by a moral dilemma that demands the ability to make decisions in very dilemmatic situations. Moral acts in harmony with moral thinking can only be achieved through emotional and spiritual empowerment and habituation. Technically, the planting of positive characters will be more effective if done through model exemplary of self-awareness. In this case the parties who are related to the implementation of education on campus must participate in providing exemplary / good example to the students.

Lecturers, staff, and senior students should provide examples of honest, disciplined, creative, and critical behaviors to junior college students. With a conducive environment, seeding positive characters will be more easily accepted and emulated by new students. By getting used to avoiding plagiarism in making scientific work, as well as doing honest lecture assignments, students have instilled positive character in themselves. One thing that is a character education media for students is through the integration of character education into the taught Courses. To realize character education for students, need to be integrated in learning in each course. One effective way of converting or compiling teaching materials or modules is by developing a model of character education with the norms or values of characters in the context of everyday life. Thus, character learning values not only on the cognitive level, but touch on internalization, and real practice in the daily life of the student in society. One of them is by developing an integrated learning model of character into the Civic Lecture. To provide a more detailed and clear picture along with the framework for the development of the Character Education Model Reconstruction in the course of Citizenship Education in Higher Education, as illustrated in Figure 1 of the following framework of thought.

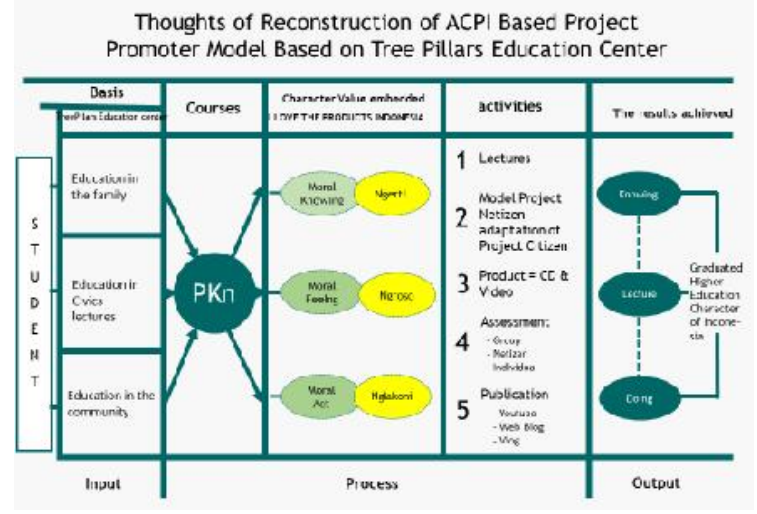

Fig. 1. The Foundation of Reconstruction Thought Character Model of ACPI-Based Netizen Project Based on Education Education Center [6]. 


\section{METHOD}

Theoretically and methodologically, this present research employed a qualitative approach supported by a quantitative approach. The method employed is Research and Development (R \& D) [7] and the data were analyzed using a mixing method, namely qualitative approach integrated with quantitative one. Research and Development (R \& D) method is a research process used to develop and validate educational products, and one of the products that would be developed is a learning program [7]. Research and development is a process or step to develop a new product, or to perfect the existing product to make the product able to be accounted for [8]. Reconstruction of Character education model is done with 3 (three) Phases, namely; 1) the development stage of the model concept, 2) the model product development stage, and 3) the model trial stage designed based on ADDIE theory [9].

\section{RESULT AND DISCUSSION}

Reconstruction of Character education model is done with 3 (three) Phases, namely; 1) the development stage of the model concept, 2) the model product development stage, and 3) the model trial stage. The third stage description of the development stage is described as follows.

\section{A. Development of Model Design}

The development of model design begins with the development of concept models. Further product development was done, and the product trial was ended (see Figures 4 and $5)$. The conceptual model is analytical that provides or explains the components of the product to be developed and the interconnectedness of its components. A model is a visual or verbal representation of a learning design process used to direct and complement the design in various educational and training settings. The conceptual model shows the interconnected relationships with one another, in which case the concepts do not show sequences gradually. One concept or component no earlier than another concept or component. The order can start from anywhere. The conceptual model is more constructivist, meaning the order is open, recurrent or recursive and flexible.

\section{B. Concept Development Design and Procedure}

At this stage will be presented the properties of components at each stage in the development, analytical explanation of component functions in each stage of product development, and explanation of the relationship between components in the system. In understanding the model of learning system design needs to be known and grouped model of learning system design.

Model of learning system design can be classified into three groups [10]. The division of this classification is based on the orientation of the use of the model, that is; 1) Classroom oriented model design model, 2) Product oriented model of product design, and 3) System-oriented model of system learning design.

The product-oriented model of product design system is based on the assumption that the design of ACPI Project Netizen character education model is based on "tripilar" education center as the strengthening of Civic Course developed within a certain period of time. This learning design model applies a very strict requirement analysis process.

The users of the character model education products generated through the application of the learning system design on this model usually have no direct contact with the program developers. Direct contact between program users and program developers only occurs during the evaluation process of the program prototype. Character education model through ACI's netizen project based on Tripilar Education Center is based on four basic assumptions, namely: 1) Product model of character education in Higher Education is indispensable, 2) Product model of education of this new character needs to be produced, 3) Product model of character education requires a trial and revision process, 4) The character model education product can be used even with the guidance of the facilitator [11].

The design of this development program has 6 (six) main components [12]. These six components focus on different elements of the design and development effort: (1) Students and how they learn, (2) the context of where learning and performance emerge, (3) the nature of the learning content and how it is sequenced, (4) Learning strategies and activities implemented, (5) Media and delivery systems used, and (6) The designer himself and the process they follow. Grand Design Character Education Based on Education Center Levels in Higher Education can be described as in figure 2 below Still under Review.

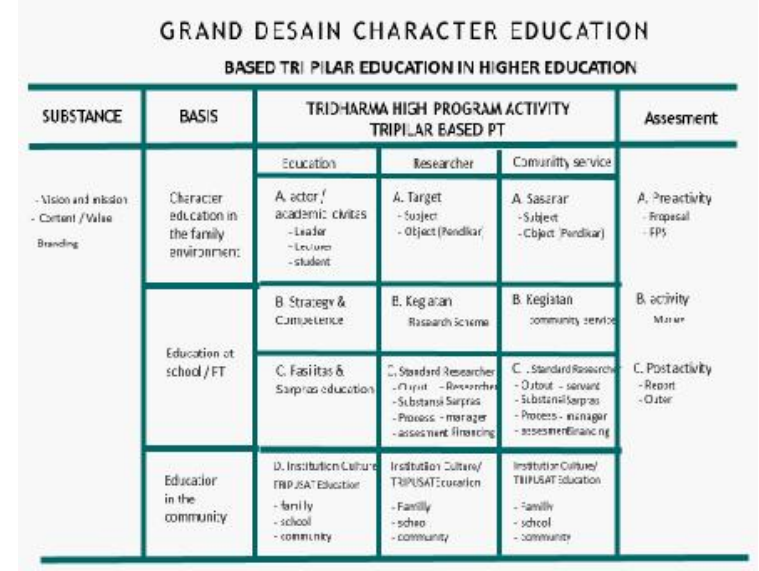

Fig. 2. Grand design Character Education Based on Tripilar Education Center in Higher Education [13].

\section{Activity Setting}

The setting of the activity begins by identifying the number of institutional characteristics, the educational aspects of the gay character of the nation that have been developed in the institution, and determining the competencies to be studied by labeling the character. Integrated learning process in-between learning theory of Civic Education and practice of making project netizen I LOVE PRODUCTS INDONESIA.

\section{Participants}

Participants at this stage of development are experts (experts) for internal validation and practitioners (lecturers) 
Civic Education Course. Validator of educational design / technology experts, content / language experts with requirements; 1) Minimum educated S3, and 2) experts in the field. While the practitioner is a lecturer of the selected PT. The assessment of experts / practitioners on learning tools includes: format, language, illustration and content. Based on input from experts, learning materials are revised to make it more precise, effective, easy to use, and have high technical quality.

At the expert review stage, product concepts that have been designed are reviewed, evaluated and evaluated by experts. The expert examines the components, the interrelationships between the components, and the language of the model concept. Expert advice is used to revise developed concepts. At this stage, the responses and suggestions from the (validator) experts about the design concepts of models that have been made are written on the validation sheet as a revised material and state that this design has been valid or not. The respondents of the development stage of the concept model are design experts as internal validators who will validate the results of the development of the concept of character education model. The next respondent was a practitioner external validator is a lecturer of Citizenship Education Course as a product user.

\section{E. Development Instruments}

In the development phase of the concept model, the instrument is the researcher himself, the checklist and the interview guide. A checklist is used to obtain notes from experts who validate the concept of the model (internal validation) and from the user lecturer (external validation) while the interview guide is used in order that the interviews with the relevant parties do not deviate from the research objectives. These guidelines are structured not only based on research objectives but also on theories related to the character education model. In addition interview guidelines as an ingredient in writing the results of research because if researchers rely solely on the ability of memory is very limited researchers worried data that has been obtained there is forgotten. The use of interview model is of course adapted to the existence of data in the field required by the author. For structured interviews, first prepare a set of questions by classifying the question forms. In the development phase of the concept of the model all data is qualitative, which describes the state or phenomenon that is happening.

\section{F. Product Development}

The product was developed in the form of character education model through Project Netizen ACPI through strengthening character education based on Tripilarr education center (family, school and community) on Civic Education Course at university. The developed model components are focused on lecturing strategies or delivery strategies. Reconstruction of Character Education Model and Development of a good learning model should be implemented through a research and development (R \& D) research. The step is right to find solutions to improve lecture practices. $\mathrm{R} \&$ $\mathrm{D}$ is a combination of basic research (basic research) with applied research (applied research).Both aims to develop learning formats, self-evaluate, and develop teaching materials that suit your needs. During this time many lecturers in universities that make up the learning model but not through a series of research, so that the model is prepared not have a strong footing ground, both in terms of theoretical and practical. The strength of the development of the learning model through R \& D lies in the aspects of the method, namely the testing so that the product can be received in terms of accuracy, suitability, clarity, accuracy, up to date, and creativity in terms of content, design, and language.

\section{G. Product Testing}

The product trial is intended to achieve valid product learning model criteria. The test is done through 2 (two) phases namely a) action research (action research) and experiment (quasi experiment). Action research aims to find out whether the teaching materials procedure is qualified or not yet while the experiment is quasi experiment or quasi experiment that aims to test the effectiveness and usefulness of the model.

\section{H. Product and Publication of Reconstruction Result of Character Model of ACPI Developed Netizen Project}

As a product of the Reconstruction of Character Education Model Project Netizen I Love Indonesian Products, the result of its development is realized in a student work in the form of project making project group of netizens whose development is taken from the concept of citizenship project or project citizen. Project Netizen can be viewed and accessed directly by students and all interested parties including parents and lecturers from the internet through You Tube, and later will be made a house (Webb blog, Pronet "Aku Cinta Produk Indonesia" I LOVE INDONESIAN PRODUCT). In addition, ask the future can also be developed through other Social Media, such as WhatsApp (WA), Instagram, Telegram and Vlog (Video blog) as illustrated in Figure 3 of the following

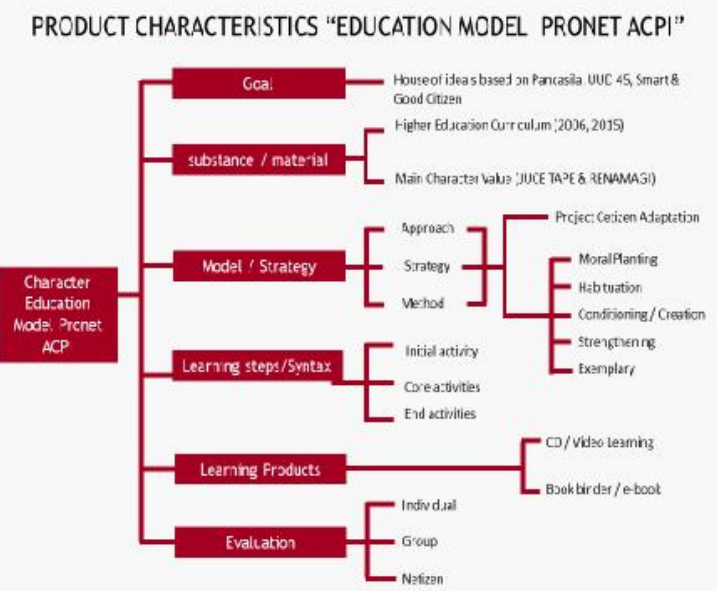

Fig. 3. Product Characteristics "Pronet ACPI Character Education Model" [6]

\section{CONCLUSION}

Based on the description in advance, it can be concluded that the reconstruction of character education model (learning model) on the course of Civic Education should be through a series of development research so as to be able to give birth to different learning models than before. This is because the preparation of the model has 
considered empirical data that can be accounted for, as well as practical considerations of better lectures, with an effective, efficient, interesting/motivational, and acceptable appearance. The research will be better if implemented by institutions that have adequate authority and capability. The Association of Pancasila Educators and Indonesian Citizens, for example, is expected to become one of the supporting institutions and implementers of this research, so that universities will immediately implement the Civics courses in accordance with the achievement of learning or learning outcomes (LO) expected by the government and society.

\section{REFERENCES}

[1] Rencana Strategis Departemen Pendidikan Nasional Tahun 2010-2014: Rancangan RPJMN tahun 2010-2014. Jakarta: Biro Perencanaan Setjen Kemendiknas.

[2] M. Belferik, "Grand Desain Pendidikan Karakter Generasi Emas 2045". Jurnal Pendidikan Karakter, Tahun III, Nomor 1, 2016.

[3] A. Wibowo, Pendidikan Karakter di Perguruan Tinggi; Membangun Karakter Ideal Mahasiswa di Perguruan Tinggi.Yogyakarta: Pustaka Pelajar, 2014.

[4] S. Suyanto, Urgensi Pendidikan Karakter, Makalah. 2012. http://www. mandikdasmen. Depdik-nas.go.id/web/pages/urgensi.html Retrieved 13 September 2015).

[5] D. Zuchdi, Humanisasi Pendidikan: Menemukan Kembali Pendidikan Yang Manusiawi. Jakarta: PT. Bumi Aksara, 2018
[6] M. Syaifudin, N. Zuriah and M. Taufik, Rekonstruksi Model Pendidikan Karakter Bangsa Berbasis Tripilar Pusat Pendidikan di Perguruan Tinggi - Laporan Kemajuan Penelitian PUPT Tahap III Tahun 2017. Ditbinlitabmas Dikti, 2017.

[7] M.D. Gall, J.P. Gall and W.R. Borg, Educational Research: An Introduction. Boston: Pearson Education, 2007.

[8] N. Syaodih Sukmadinata, Metode Penelitian Pendidikan, Bandung: Remaja Rosda Karya, 2005.

[9] M. Molenda, In search of the ellusive ADDIE model. Pervormance improvement, 42 (5), 34-36. Submitted for publication in A. Kovalchick \& K. Dawson, Ed's Educational Technology: An Encyclopedia. Copyright by ABC- Clio, Santa Barbara, CA, 2003.

[10] K.L. Gustafson and R.M. Branch, Surveyof Instructional Development Models. Syracuse University, Syracuse, NY: ERIC Clearing house on Information \& Technology, 2002.

[11] S. Winarni, "Integrasi Pendidikan Karakter Dalam Perkuliahan". Jurnal Pendidikan Karakter, FIK Universitas Negeri Yogyakarta, Tahun III, Nomor 1, Februari 2013.

[12] R.C. Richey and J.D. Klein, Design and Development Research. New York: Routledge, 2007.

[13] M. Syaifudin, N. Zuriah and M. Taufik, Rekonstruksi Model Pendidikan Karakter Bangsa Berbasis Tripilar Pusat Pendidikan di Perguruan Tinggi - Laporan Penelitian PUPT Tahap II Tahun 2016. Ditbinlitabmas Dikti, 2016. 